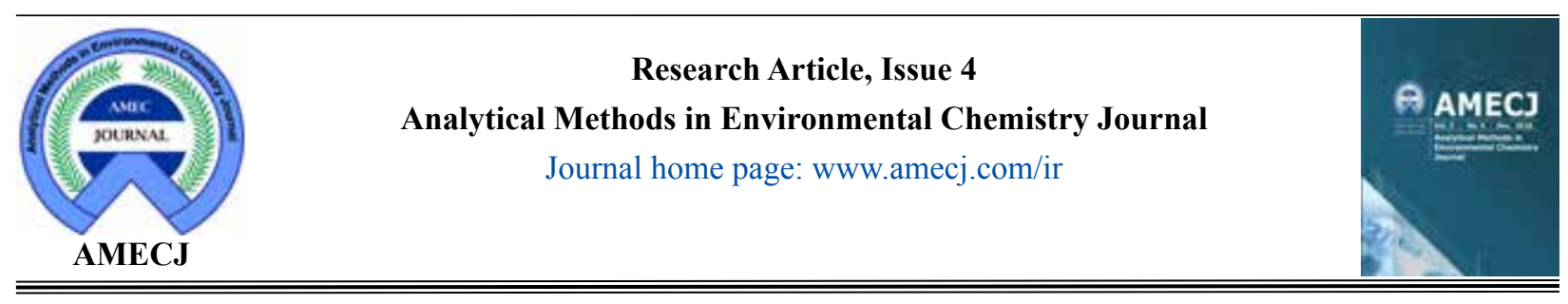

\title{
Zinc based metal-organic framework for nickel adsorption in water and wastewater samples by ultrasound assisted- dispersive-micro solid phase extraction coupled to electrothermal atomic absorption spectrometry
}

\author{
Negar Motakef Kazemia,* \\ a, ${ }^{*}$ Department of Medical Nanotechnology, Faculty of Advanced Sciences and Technology, Tehran Medical Sciences, Islamic \\ Azad University, Tehran, Iran
}

\begin{abstract}
A R T I C L E I N F O :
Received 14 Sep 2020

Revised form 15 Nov 2020

Accepted 30 Nov 2020
\end{abstract}

Available online 29 Dec 2020

Keywords:

Metal-organic framework,

Nickel,

Adsorption,

Dispersive- micro solid phase

extraction,

Water sample,

Electrothermal atomic absorption spectrometry

\begin{abstract}
A B S T R A C T
In this research, $\mathrm{Zn}_{2}(\mathrm{BDC})_{2}(\mathrm{DABCO})$ metal-organic framework (MOF) as a solid phase was used for separation and preconcentration toxic nickel ions (Ni) from water samples by ultrasound assisteddispersive-micro solid phase extraction coupled to electrothermal atomic absorption spectrometry (USA-D- $\mu-S P E / E T-A A S)$. The MOF nanostructure was characterized by field emissionscanning electron microscope (FE-SEM) and transmission electron microscopey (TEM) for presentation of morphology and size of MOF synthesis. By procedure, $25 \mathrm{mg}$ of $\mathrm{Zn}_{2}(\mathrm{BDC})_{2}(\mathrm{DABCO})$ as $\mathrm{MOF}$ adsorbent was added to $25 \mathrm{~mL}$ of water samples and then, $\mathrm{Ni}$ ions chemically adsorbed based on dative bonding of nitrogen in DABCO (1,4-diazabicyclo [2.2. 2] octane); $\left.\mathrm{N}_{2}\left(\mathrm{C}_{2} \mathrm{H}_{4}\right)_{3}\right)$ at $\mathrm{pH}=8$. The adsorbent was separated from liquid phase by syringe cellulose acetate filters (SCAF, $0.2 \mu \mathrm{m}$ ) and Ni ions back extracted from MOF adsorbent before determined by ET-AAS. The maximum recovery of MOF for nickel ions as a physically and chemically adsorption was obtained $34.6 \%$ and $98.8 \%$ at $\mathrm{pH}=3$ and 8 , respectively. The capacity adsorption of $\mathrm{Zn}_{2}(\mathrm{BDC})_{2}(\mathrm{DABCO})$, MOF for nickel was acquired $125.7 \mathrm{mg} \mathrm{g}^{-1}$ at $\mathrm{pH}=8$. By procedure, the preconcentration factor $(\mathrm{PF}), \mathrm{LOD}$, and linear range were achieved 48.7, $0.03 \mu \mathrm{g} \mathrm{L} \mathrm{L}^{-1}$ and $0.10-2.88 \mu \mathrm{g} \mathrm{L}^{-1}$, respectively $(\mathrm{RSD}<1.26)$. The validation of proposed method was successfully obtained by ICP-MS analysis in real samples.
\end{abstract}

\section{Introduction}

The water pollution is one of the most important issues in the world today [1-2]. The high concentration of heavy metals in environment has been attributed to population growth, economic

\footnotetext{
*Corresponding Author: Negar Motakef Kazemi

Email: motakef@iaups.ac.ir

https://doi.org/10.24200/amecj.v3.i04.123
}

development and rapid industrialization in recent years [3-5]. These toxic metals can enter to the human body after release into the environment. Exposure to heavy metals causes to poisoning, mutagenicity, carcinogenicity and disease in humans, as well as a serious threat to the environment and public health [6]. Nickel is one of the most toxic heavy metal for humans even in 
low concentrations. Nickel toxicity causes some disorders in human body such as bone diseases, damage to the liver and the kidney, bronchitis, lung cancer and CNS problem $[7,8]$. Nickel ions enter into environment from waste water, water and air from industries and factories such as battery Company, mining and electroplating. Normal range of nickel in human serum $\left(0.2 \mu \mathrm{gL}^{-1}\right)$ is reported by American conference of governmental industrial hygienists $(A C G I H)$. Also, the nickel values in water samples are ranges from 3 to $10 \mu \mathrm{g} \mathrm{L}^{-1}$ and average levels in drinking water is between 2.0$4.3 \mu \mathrm{g} \mathrm{L}{ }^{-1}[7,8]$. Recently, the different techniques include, flame atomic absorption spectrometry (F-AAS) [9], electrothermal atomic absorption spectrometry (ET-AAS) [10], ultrafiltration [11], ion-exchange [12], chemical precipitation [13], electrodialysis [14], adsorption [15], spectrophotometry [16] and inductively coupled plasma-mass spectrometry (ICP-MS) [17] were used for nickel determination in water and human biological samples. As difficulty matrixes and trace concentration in drinking waters and wastewater, the sample preparation must be used to separation $\mathrm{Ni}$ ions from samples. The different procedures for sample preparation of $\mathrm{Ni}$ were reported in water samples. For examples, the solid-phase extraction (SPE), the functionalized magnetic SPE [18], the dispersive liquid-liquid microextraction method (DLLME) [19], ultrasound-assisted solid phase extraction (USA-SPE) [20] and micro SPE (D- $\mu$-SPE)[21] were previously presented for preparation of water samples by researchers. Today, the nanotechnology has led to significant advances in different fields of science and product innovation [22]. Nanomaterials have been developed due to their special properties and various application potentials [23, 24]. Recently, the metal-organic frameworks (MOFs) have expanded as porous hybrid organic-inorganic materials $[25,26]$. These materials synthesized via self-assembly of primary building blocks including metal ions (or metal clusters) as metal centers, and bridging ligands as linkers [27]. MOFs have been synthesized by different methods such as solvothermal, hydrothermal, ionic liquids, microwave, sonochemical, diffusion, electrochemical, mechanochemical, and laser ablation [28]. MOFs have received great attention because of their unique properties in many areas [28-29]. The ultrasound assisted-dispersive ionic liquid-suspension solid phase micro extraction is a good candidate method for $\mathrm{Ni}$ extraction from waters [30].

In the present study, the nickel absorption is one of the most considerable applications of $\mathrm{Zn}_{2}(\mathrm{BDC})_{2}(\mathrm{DABCO}) \mathrm{MOF}$ in waters. So, The $\mathrm{Zn}$ MOF adsorbent based on USA-D- $\mu$-SPE procedure was used for nickel adsorption/extraction from water samples and the concentration of nickel ions determined by ET-AAS.

\section{Experimental}

\subsection{Materials}

All reagents with high purity and analytical grade were purchased from Merck (Darmstadt, Germany). Materials including zinc acetate dihydrate $\left(\mathrm{Zn}(\mathrm{OAc})_{2} .2 \mathrm{H}_{2} \mathrm{O}\right), 1,4$ benzenedicarboxylicacid(BDC), 1,4-diazabicyclo [2.2.2] octane (DABCO), dimethylformamide (DMF) were purchased and used for synthesis of $\mathrm{Zn}_{2}(\mathrm{BDC})_{2}(\mathrm{DABCO}) \mathrm{MOF}$. The syringe cellulose acetate filters (SCAF, $0.2 \mu \mathrm{m}$ ) purchased from Sartorius, Australia (Minisart ${ }^{\circledR}$ Syringe Filters). The GBC 932, electrothermal atomic absorption spectrophotometer (ET-AAS, model 932, Australia) equipped with a graphite furnace were used for the determination of nickel in water samples. The samples were injected to graphite tube with auto-sampler $(20 \mu \mathrm{L})$. The ICP-MS was used for determining of ultra-trace nickel in water samples (Perkin Elmer, $1200 \mathrm{~W} ; 2.0 \mathrm{~L} \mathrm{~min}^{-}$ 1; 1-1.5 sec per mass; N2 gas). The $\mathrm{pH}$ meter with the glassy electrode was used for measuring $\mathrm{pH}$ in water samples (Metrohm, E-744, Switzerland). The shacking of water and wastewater samples were done by vortex mixer (Thermo, USA). The standard solution of nickel nitrate $(1 \%$, $\mathrm{Ni}(\mathrm{NO} 3)_{2}$ was purchased from Sigma, Germany. All of Ni standard 0.5-5 ppb was daily prepared 
by dilution of the standard Ni solution with DW. Ultrapure water was prepared from RIPI Co. (IRAN). The $\mathrm{pH}$ was adjusted from 5.5 to 8.0 by sodium phosphate buffer solution $(0.2 \mathrm{M}$, Merck, Germany).

\subsection{Characterization}

The MOF was characterized by scanning electron microscope (FESEM) (SIGMA VP) and transmission electron microscope TEM (EM10C) microscopes from Zeiss Company. $\mathrm{X}$-ray diffraction (XRD) spectrum were prepared by a Seifert TT 3000 diffractometer (Germany) using wavelength $0.15 \mathrm{~nm}$. The Fourier transform infrared spectrophotometer (FTIR, IFS 88, Bruker Optik GmbH, Germany) was used in the 200-4000 $\mathrm{cm}^{-1}$. Determination of nickel was performed with ET-AAS.

\subsection{Synthesis of MOF}

The $\mathrm{Zn}_{2}(\mathrm{BDC})_{2}(\mathrm{DABCO})$ MOF was prepared via the self-assembly of $\mathrm{Zn}^{2+}$ ion as a connector, $\mathrm{DABCO}$ as a bridging ligand, and BDC as a chelating ligand. In a typical reaction, $\mathrm{Zn}$ $(\mathrm{OAc})_{2} .2 \mathrm{H}_{2} \mathrm{O}(0.132 \mathrm{~g}, 2 \mathrm{mmol})$, BDC (0.1 g, $2 \mathrm{mmol})$, and DABCO (0.035 $\mathrm{g}, 1 \mathrm{mmol})$ were added to $25 \mathrm{ml}$ DMF [4]. The reactants were sealed under reflux and stirred at $90{ }^{\circ} \mathrm{C}$ for 15 min. Then, the reaction mixture was cooled to room temperature, and filtered. The white crystals were washed with DMF to remove any metal and ligand remained, and dried in a vacuum. DMF was removed from white crystals with a vacuum furnace at $150{ }^{\circ} \mathrm{C}$ for $5 \mathrm{~h}$.

\subsection{General procedure of nickel adsorption}

By proposed method, the $\mathrm{Zn}_{2}(\mathrm{BDC})_{2}(\mathrm{DABCO})$ as metal-organic framework (MOF) was used for extraction of toxic nickel ions $\left(\mathrm{Ni}^{2+}\right)$ from water samples by USA-D- $\mu$-SPE procedure (Fig.1). Firstly, $25 \mathrm{mg}$ of $\mathrm{Zn}_{2}(\mathrm{BDC})_{2}(\mathrm{DABCO})$ adsorbent added to $25 \mathrm{~mL}$ of water samples included $\mathrm{Ni}$ standard solution and $\mathrm{Ni}$ ions chemically adsorbed based on dative bonding of nitrogen groups in DABCO material after shaking for 10 min at $\mathrm{pH}=8$. Secondly, the $\mathrm{Zn}_{2}(\mathrm{BDC})_{2}(\mathrm{DABCO})$ adsorbent separated from water samples by SCAF $(10 \mathrm{~mL}, 0.2 \mu \mathrm{m})$ and then the Ni loaded on the MOF was back-extracted from solid-phase based on changing $\mathrm{pH}$ by nitric acid solution $(0.2 \mathrm{M}$, $0.25 \mathrm{~mL}$ ). After dilution, the remained solution was determined by ET-AAS after dilution with DW up to $0.5 \mathrm{~mL}$. Also, the adsorptions of the $\mathrm{Zn}_{2}(\mathrm{BDC})_{2}(\mathrm{DABCO})$ adsorbent were evaluated in different $\mathrm{pH}$ by USA-D- $\mu$-SPE procedure and capacities adsorption was obtained. The proposed procedure was used for a blank solution without any analyte $(\mathrm{Ni})$ for 10 times. The calibration curve for nickel in was prepared from LLOQ to ULOQ ranges $\left(0.1-2.88 \mu \mathrm{g} \mathrm{L}^{-1}\right)$ and the PF obtained by the curve-fitting rule.

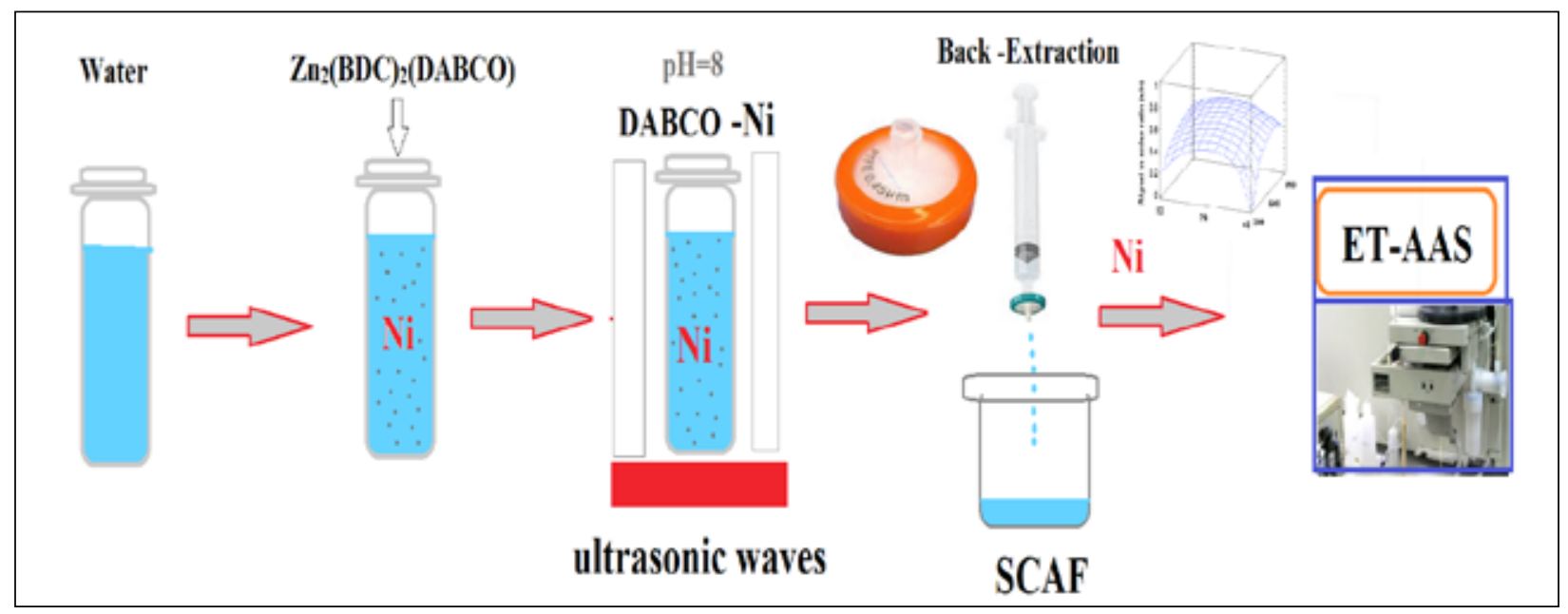

Fig. 1. Extraction procedure for nickel ions in water by $\mathrm{Zn}_{2}(\mathrm{BDC})_{2}(\mathrm{DABCO})$ adsorbent 


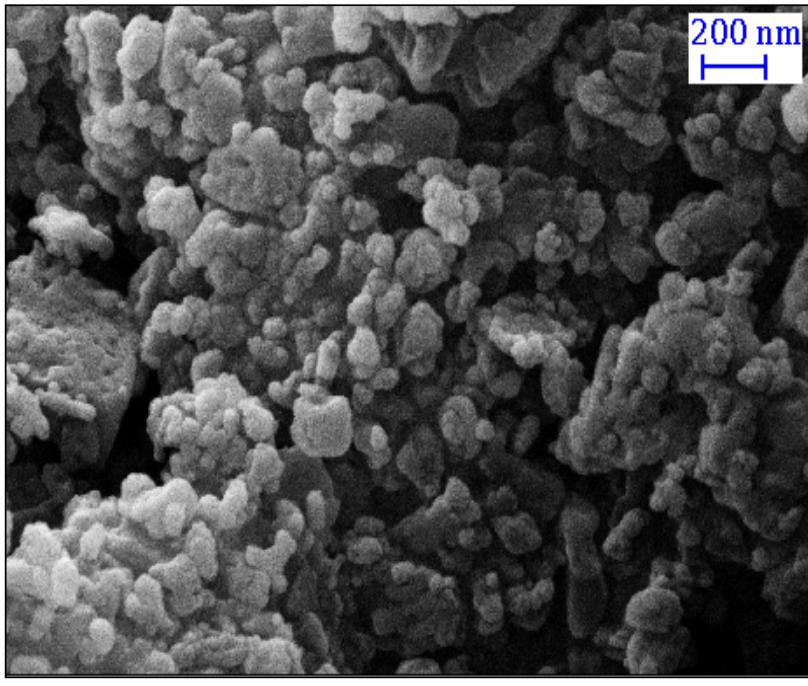

Fig. 2a. FESEM of $\mathrm{Zn}_{2}(\mathrm{BDC})_{2}(\mathrm{DABCO}) \mathrm{MOF}$

\section{Results and Discussion}

\subsection{FE-SEM and TEM}

Field emission scanning electron microscope (FESEM) was used for evaluation of morphology of MOF $\left[\mathrm{Zn}_{2}(\mathrm{BDC})_{2}(\mathrm{DABCO})\right]$ with an average diameter of $100 \mathrm{~nm}$ (Fig. 2a). Transmission electron microscope (TEM) was used for evaluation of nanoparticles size and morphology of the MOF. TEM showed the pore shape and size, the pore has rod-shaped with many pore with different sizes from 20-80 nm (Fig. 2b).

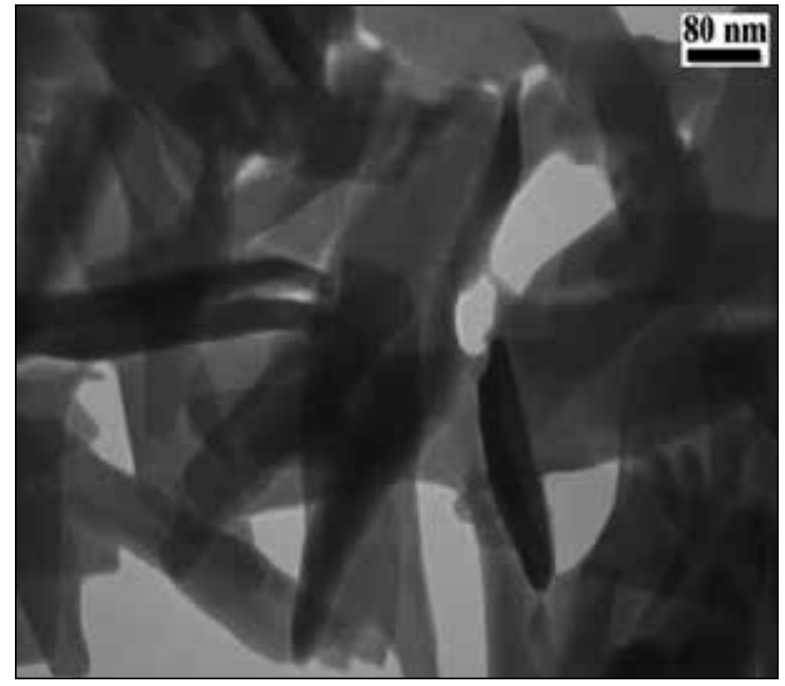

Fig. 2b. TEM of $\mathrm{Zn}_{2}(\mathrm{BDC})_{2}(\mathrm{DABCO}) \mathrm{MOF}$

\subsection{FTIR of $Z n_{2}(B D C)_{2}(D A B C O) M O F$}

The organic material and functional groups such as $\mathrm{NH}, \mathrm{CO}, \mathrm{SH}$ in different adsorbents were identified by FTIR analysis. The FTIR spectrum of $\mathrm{Zn}_{2}(\mathrm{BDC})_{2}(\mathrm{DABCO}) \mathrm{MOF}$ was obtained after calcination in $\mathrm{KBr}$ matrix $\left(250^{\circ} \mathrm{C}\right)$. As results, there is no peak based on impurities and and it confirm the completion of the synthesis. Also, various peaks were presented such as $705 \mathrm{~cm}^{-1}$ and 1000 $\mathrm{cm}^{-1}$ for $\mathrm{ZnO}$ bonds, $3000 \mathrm{~cm}^{-1}-3500 \mathrm{~cm}^{-1}$ for $\mathrm{OH}$ of carboxylic acid, $1600 \mathrm{~cm}^{-1}$ for $\mathrm{CO}$ stretching

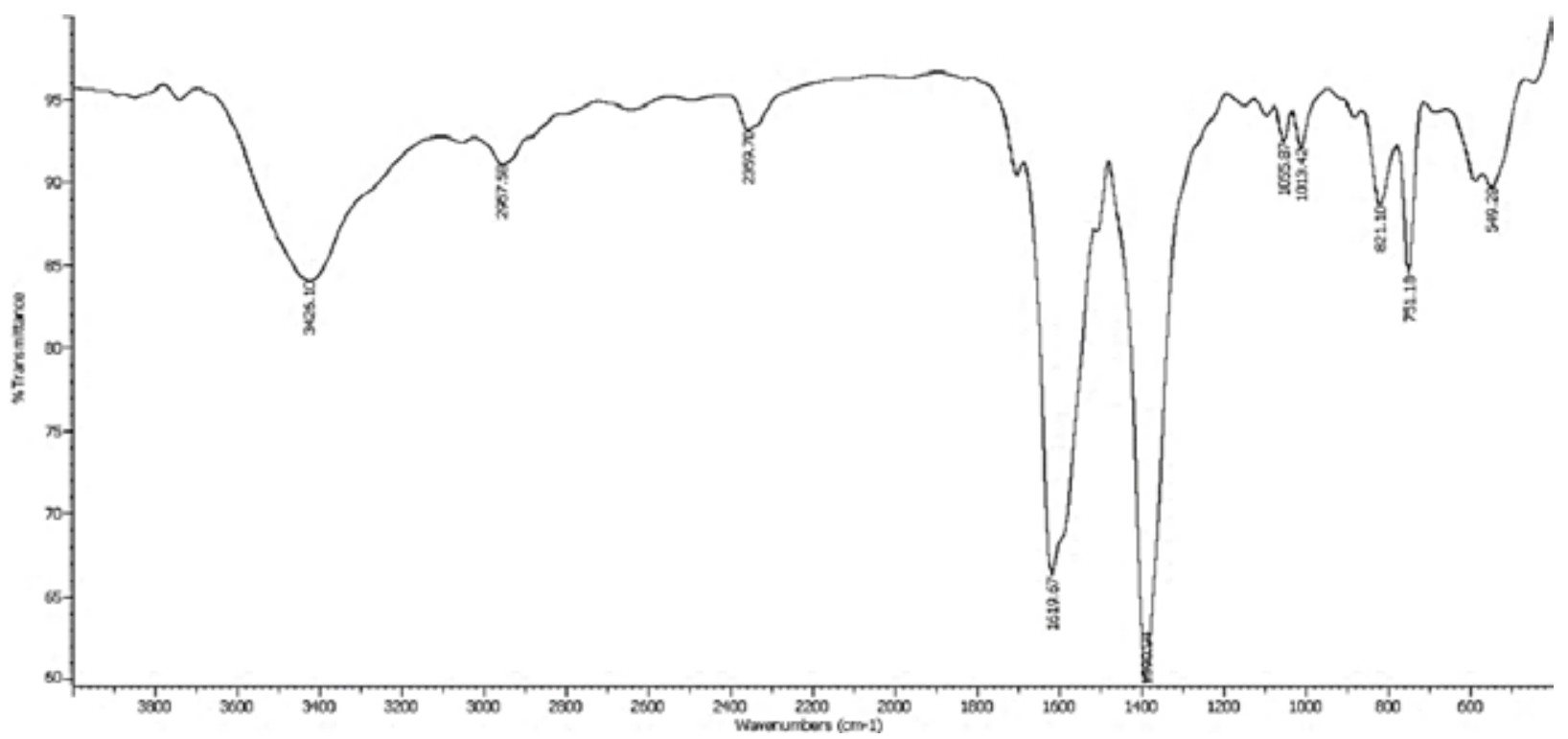

Fig. 3. FTIR spectrum of the $\mathrm{Zn}_{2}(\mathrm{BDC})_{2}(\mathrm{DABCO}) \mathrm{MOF}$. 
bond and $1440 \mathrm{~cm}^{-1}, 1358 \mathrm{~cm}^{-1}, 1429 \mathrm{~cm}^{-1}$ and $1550 \mathrm{~cm}^{-1}$ for aromatic compounds (Fig.3).

\section{3. $X R D$ of $Z n_{2}(B D C)_{2}(D A B C O) M O F$}

By application of XRD technique, the essential information can obtain based on crystal structure and product purity by XRD analysis. The XRD pattern for the $\mathrm{Zn}_{2}(\mathrm{BDC})_{2}(\mathrm{DABCO}) \mathrm{MOF}$ was shown in Figure 4. By results, all peaks are clear. In addition, the XRD pattern for the $\mathrm{Zn}_{2}(\mathrm{BDC})_{2}(\mathrm{DAB}-$ $\mathrm{CO})$ has no peak belong to impurities. The crystal structure of the $\mathrm{Zn}_{2}(\mathrm{BDC})_{2}(\mathrm{DABCO})$ confirm by sharp peaks of XRD pattern. The size of the $\mathrm{Zn}_{2}(\mathrm{~B}-$ $\mathrm{DC})_{2}(\mathrm{DABCO}) \mathrm{MOF}$ was achieved about $45 \mathrm{~nm}$ by Debye-Scherrer equation.

\subsection{The pH optimization}

The $\mathrm{pH}$ is the effective factor on adsorption and extraction of nickel ions by USA-D- $\mu$-SPE procedure. So, the different $\mathrm{pH}$ between 2-10 was studied for extraction of $\mathrm{Ni}$ (II) in water and wastewater samples. The experimental results showed us, the $\mathrm{Zn}_{2}(\mathrm{BDC})_{2}(\mathrm{DABCO})$
MOF was simply extracted Ni (II) ions from water samples in a $\mathrm{pH} 7.5-8.5$. Moreover, the extraction efficiency was achieved about $98.7 \%$ in $\mathrm{pH}$ of 8 but, the recoveries were reduced at acidic $\mathrm{pH}$ less than 7 and basic $\mathrm{pH}$ more than 9.0. So, the optimum $\mathrm{pH}$ of 8 was used for further works in this study. The extraction mechanism of nickel ions in water samples based on $\mathrm{Zn}_{2}(\mathrm{BDC})_{2}$ (DABCO) MOF take place by the coordination of dative covalent bond of $\mathrm{N}$ group as negative charge with the positively charged $\mathrm{Ni}$ ions $(\mathrm{Ni} \rightarrow: \mathrm{N})$ at $\mathrm{pH}=8$. At lower $\mathrm{pH}$ $\left(\mathrm{pH}<\mathrm{pH}_{\mathrm{PZC}}\right)$, the surface of $\mathrm{Zn}_{2}(\mathrm{BDC})_{2}(\mathrm{DABCO})$ MOF have positively charged and extraction efficiency decreased as repulsion. Also, the surface of $\mathrm{Zn}_{2}(\mathrm{BDC})_{2}$ (DABCO) MOF have negatively charged at $\mathrm{pH}=8$ and so the negative charge between nitrogen group and $\mathrm{Ni}^{2+}$ caused to increased recovery. At $\mathrm{pH}$ more than 8 , the $\mathrm{Ni}$ ions started to participate $\left(\mathrm{Ni}(\mathrm{OH})_{2}\right)$ and so, the recovery decreased (Fig. 5). The best $\mathrm{pH}$ for physical adsorption was achieved at $\mathrm{pH}$ between 3-4 with the mean recovery of $34.6 \%$.

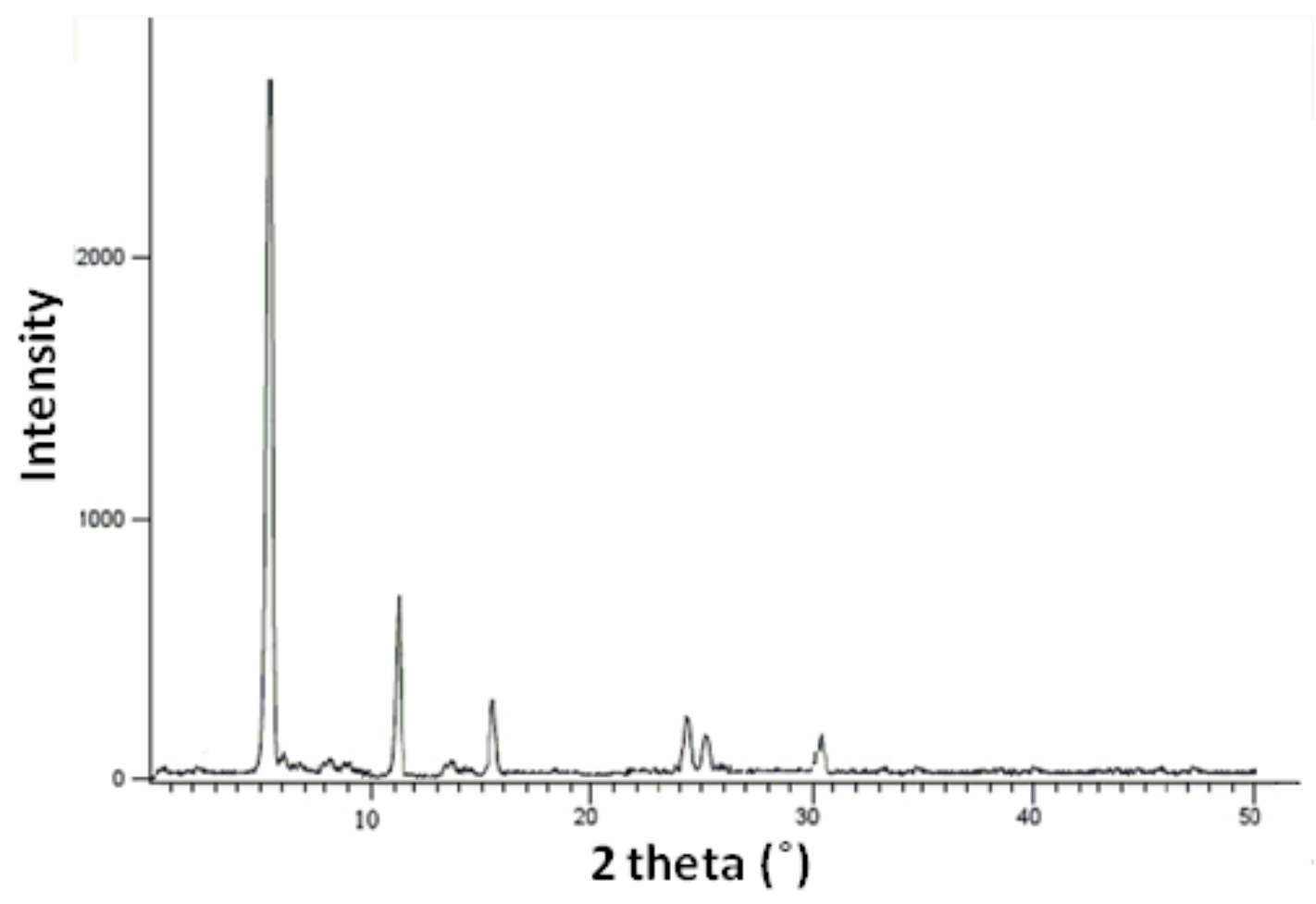

Fig.4. XRD pattern of the synthesized $\mathrm{Zn}_{2}(\mathrm{BDC})_{2}(\mathrm{DABCO}) \mathrm{MOF}$ 


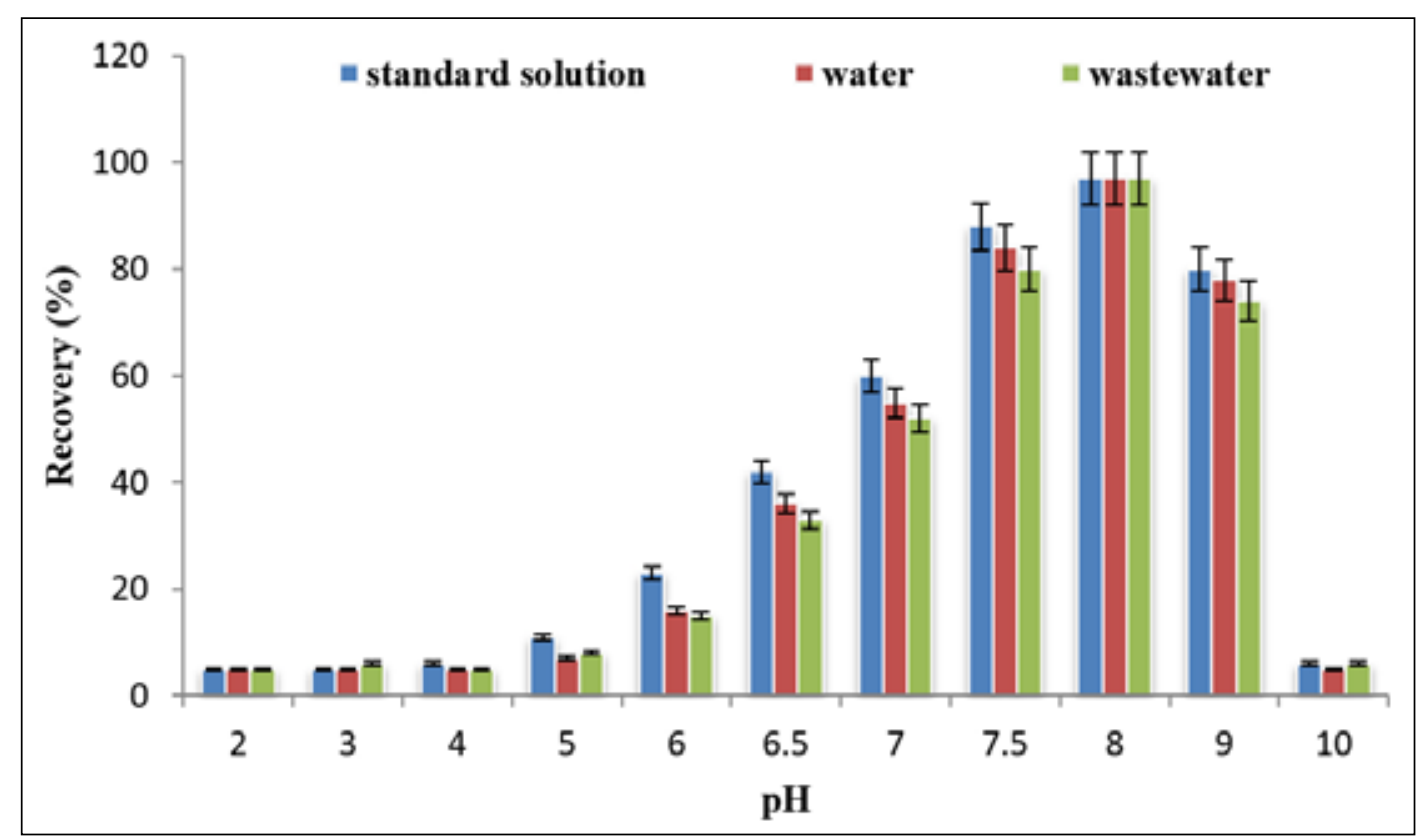

Fig. 5. The effect of $\mathrm{pH}$ on nickel extraction in water samples based on $\mathrm{Zn}_{2}(\mathrm{BDC})_{2}(\mathrm{DABCO})$ MOF by USA-D- $\mu$-SPE procedure

\subsection{The effect of sample volume}

The influence of sample volume for $\mathrm{Ni}$ extraction based on $\mathrm{Zn}_{2}(\mathrm{BDC})_{2}(\mathrm{DABCO}) \mathrm{MOF}$ was studied between 5-50 mL in water and wastewater samples with LLOQ and ULLOQ ranges (0.1-2.88 $\left.\mu \mathrm{g} \mathrm{L}^{-1}\right)$. The results showed us the high recoveries were achieved for $25 \mathrm{~mL}$ of water samples and wastewater samples. So, $25 \mathrm{~mL}$ of sample was selected as optimum volume for nickel extraction in water and wastewater samples at $\mathrm{pH}=8$. By increasing the sample volume more than $25 \mathrm{~mL}$, the extraction recoveries were reduced between $43-52 \%$ (Fig. 6).

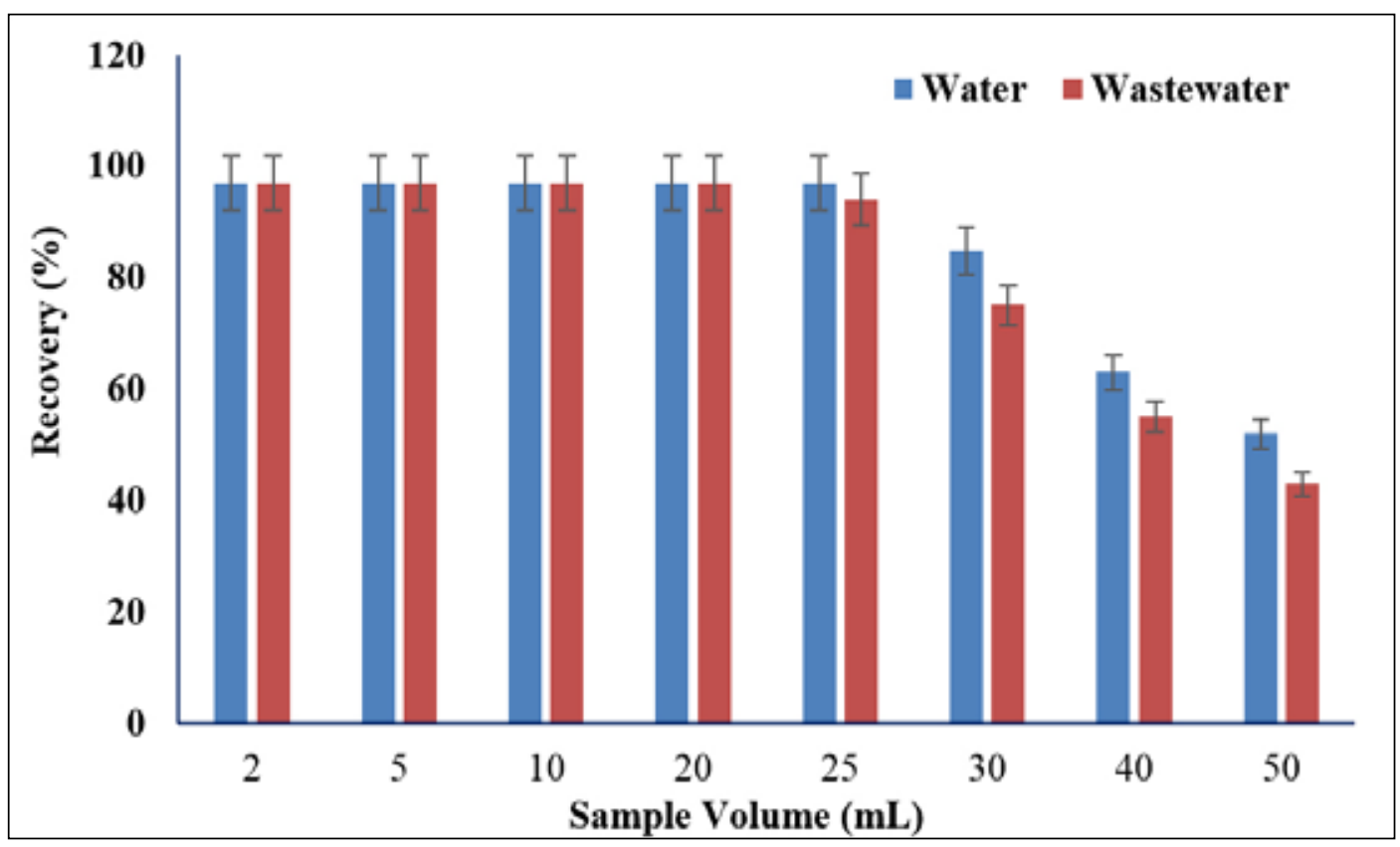

Fig. 6. The effect of sample volume on nickel extraction in water samples based on $\mathrm{Zn}_{2}(\mathrm{BDC})_{2}(\mathrm{DABCO}) \mathrm{MOF}$ by USA-D- $\mu$-SPE procedure 


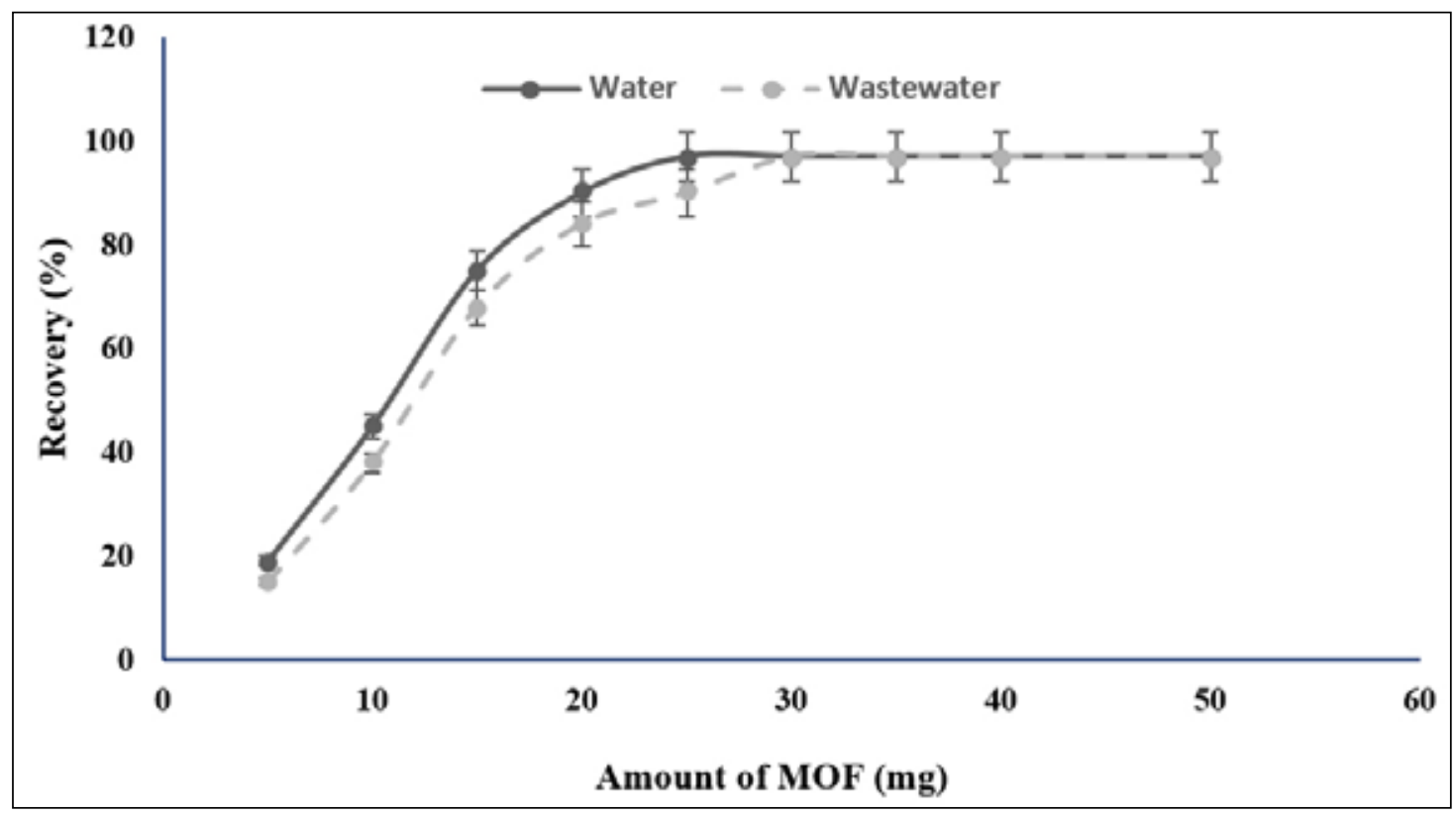

Fig. 7. The effect of MOF mass for nickel extraction in water samples based on $\mathrm{Zn}_{2}(\mathrm{BDC})_{2}(\mathrm{DABCO}) \mathrm{MOF}$ by USA-D- $\mu$-SPE procedure

\subsection{The effect of $Z n_{2}(B D C)_{2}(D A B C O) M O F$}

For efficient recovery, the amount of $\mathrm{Zn}_{2}(\mathrm{BDC})_{2}(\mathrm{DABCO})$ MOF must be evaluated and optimized. Therefore, the amounts of $\mathrm{Zn}_{2}(\mathrm{BDC})_{2}(\mathrm{DABCO}) \mathrm{MOF}$ between 5-50 $\mathrm{mg}$ were examined for $\mathrm{Ni}$ (II) adsorption/extraction by the USA-D- $\mu$-SPE procedure. The results showed that the quantitative recoveries in water samples were obtained with $22 \mathrm{mg}$ of $\mathrm{Zn}_{2}(\mathrm{BDC})_{2}$ (DABCO) MOF for nickel extraction at $\mathrm{pH}=8$. So, $25 \mathrm{mg}$ of $\mathrm{Zn}_{2}(\mathrm{BDC})_{2}(\mathrm{DABCO}) \mathrm{MOF}$ was used as optimum of MOF mass for further process (Fig. 7). The results showed us the extra dosage of MOF had no effect on the extraction value in water samples.

\subsection{The effect of eluent}

The eluents with different volume and concentration was used for back-extraction of nickel ions from $\mathrm{Zn}_{2}(\mathrm{BDC})_{2}(\mathrm{DABCO}) \mathrm{MOF}$. Acidic $\mathrm{pH}$ cause to breakdown the dative bond between nitrogen group in MOF and nickel ions (MOF-N: ..... Ni) and then, the Ni (II) ions release into the eluent phase. Therefore, a different volume of acid solution such as $\mathrm{HCl}, \mathrm{HNO}_{3}, \mathrm{H}_{2} \mathrm{SO}_{4}$ and $\mathrm{H}_{2} \mathrm{CO}_{3}$ with various concentration was examined for back extraction
$\mathrm{Ni}$ (II) in water samples $\left(0.1-1 \mathrm{~mol} \mathrm{~L}^{-1}, 0.1-0.5\right.$ $\mathrm{mL}$ ) by syringe cellulose acetate filters (SCAF, 0.2 $\mu \mathrm{m})$. The results showed that $0.2 \mathrm{~mol} \mathrm{~L}^{-1} \mathrm{HNO}_{3}$ as elution phase can efficient released the Ni (II) ions from $\mathrm{Zn}_{2}(\mathrm{BDC})_{2}(\mathrm{DABCO}) \mathrm{MOF}$ to liquid phase. So, $0.2 \mathrm{~mol} \mathrm{~L}^{-1}$ of $\mathrm{HNO}_{3}(0.1 \mathrm{~mL})$ was selected as the optimum concentration and volume of $\mathrm{HNO}_{3}$ eluent in this study. As a result, the elution of solid phase $\left(\mathrm{Zn}_{2}(\mathrm{BDC})_{2}(\mathrm{DABCO}) \mathrm{MOF}\right)$ with nitric acid $(0.2 \mathrm{M}, 0.1 \mathrm{~mL})$ was simply back extracted nickel ions from MOF (Fig.8).

\subsection{Validation}

By USA-D- $\mu$-SPE procedure, the nickel extraction based on $\mathrm{Zn}_{2}(\mathrm{BDC})_{2}(\mathrm{DABCO}) \mathrm{MOF}$ was obtained in water and wastewater samples. The experimental results showed a validated data for $\mathrm{Ni}$ (II) in tab water, drinking water, river water and wastewater samples at $\mathrm{pH}=8$ (Table 1). The accuracy of the data were confirmed by spiking of nickel standard solution to water samples based on $\mathrm{Zn}_{2}(\mathrm{BDC})_{2}(\mathrm{DABCO}) \mathrm{MOF}$ adsorbent. Due to results the efficient recovery for extraction $\mathrm{Ni}$ ions in wastewater and water samples was achieved by nanoparticles of $\mathrm{Zn}_{2}(\mathrm{BDC})_{2}(\mathrm{DABCO}) \mathrm{MOF}$. 


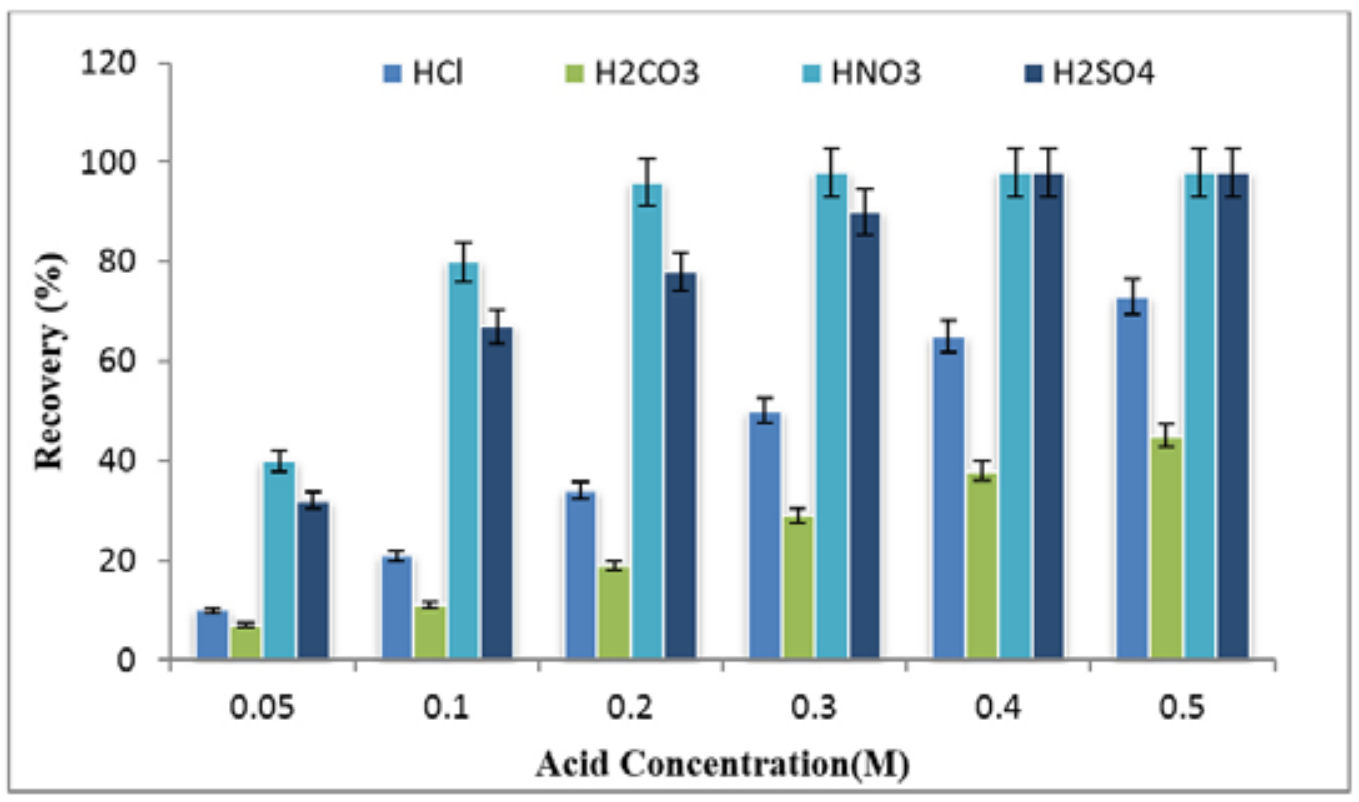

Fig. 8. The effect of eluents on nickel extraction based on $\mathrm{Zn}_{2}(\mathrm{BDC})_{2}(\mathrm{DABCO}) \mathrm{MOF}$

The perfect extraction demonstrated that the USA-D- $\mu$-SPE technique had satisfactory results for nickel in real samples at $\mathrm{pH}=8$. In addition, the standard reference materials (SRM) were used for validating of DIL-S- $\mu$-SPE procedure (Table 2).

Table 1. Validation of methodology for nickel extraction and determination in water samples by spiking of samples by USA-D- $\mu$-SPE procedure coupled to ET-AAS

\begin{tabular}{cccc}
\hline Sample & Added $\left(\mu \mathrm{L} \mathrm{L}^{-1}\right)$ & ${ }^{*}$ Found $\left(\mu \mathrm{g} \mathrm{L}^{-1}\right)$ & Recovery $(\%)$ \\
\hline \multirow{2}{*}{ Tab Water } & --- & $0.454 \pm 0.022$ & --- \\
\hline \multirow{2}{*}{ Drinking Water } & 0.5 & $0.948 \pm 0.045$ & 98.80 \\
\hline \multirow{2}{*}{ a Wastewater } & --- & $1.641 \pm 0.072$ & -- \\
Well water & 1.5 & $3.103 \pm 0.147$ & 97.46 \\
\hline \multirow{2}{*}{ River water } & --- & $1.723 \pm 0.084$ & --- \\
\hline b Sea Water & 1.0 & $2.745 \pm 0.133$ & 102.22 \\
\hline
\end{tabular}

*Mean of three determinations of samples \pm confidence interval $(\mathrm{P}=0.95, \mathrm{n}=10)$

${ }^{a}$ wastewater dilution with DW $(1: 10)$

${ }^{\mathrm{b}}$ Sea water dilution with DW (1:5) 
Table 2. Determination of nickel in water samples based on $\mathrm{Zn}_{2}(\mathrm{BDC})_{2}(\mathrm{DABCO}) \mathrm{MOF}$ by standard reference materials (SRM)

\begin{tabular}{|c|c|c|c|c|}
\hline Sample & Added $\left(\mu \mathrm{g} \mathrm{L}^{-1}\right)$ & SRM Value $\left(\mu \mathrm{g} \mathrm{L}^{-1}\right)$ & ${ }^{*}$ Found $\left(\mu \mathrm{g} \mathrm{L}^{-1}\right)$ & Recovery(\%) \\
\hline \multirow[t]{2}{*}{${ }^{a} 1643 f$} & ------- & 1.5 & $1.49 \pm 0.06$ & ------- \\
\hline & 1.5 & ------- & $2.91 \pm 0.13$ & 94.6 \\
\hline \multirow[t]{2}{*}{${ }^{\mathrm{a}} 1643 \mathrm{e}$} & ------- & 1.5 & $1.59 \pm 0.07$ & ------- \\
\hline & 1.5 & ------- & $3.15 \pm 0.15$ & 104.1 \\
\hline \multirow[t]{2}{*}{ a $1640 \mathrm{a}$} & ------ & 0.6 & $0.63 \pm 0.03$ & ------ \\
\hline & 0.5 & ------- & $1.12 \pm 0.05$ & 98.0 \\
\hline \multirow[t]{2}{*}{ b3136 } & ------- & 1.0 & $1.02 \pm 0.05$ & ------- \\
\hline & 1.0 & ------- & $1.98 \pm 0.08$ & 96.0 \\
\hline
\end{tabular}

* Mean of three determinations of samples $\pm \mathrm{SD}(\mathrm{P}=0.95, \mathrm{n}=10)$

${ }^{a}$ Standard Reference Material 1643f (1.50), 1643e (1.50) and 1640a (0.6), trace elements in water, after dilution with DW (1:40)

${ }^{\mathrm{b}}$ NIST, SRM 3136, Sigma, after dilution with DW the concentration of $1.0 \mu \mathrm{g} \mathrm{L} \mathrm{L}^{-1}$ daily prepared

\subsection{Comparing with other methods}

The USA-D- $\mu$-SPE procedure was compared to other published articles for extraction and determination of $\mathrm{Ni}$ ions in water samples (Table 3). Due to table 3, the different methodology and adsorbents compared for nickel extraction in water samples. Many parameters such as LOD,
$\mathrm{PF}, \mathrm{RSD} \%$, sample volume, capacity adsorption and etc. compared together. The results showed us, the USA-D- $\mu$-SPE procedure was comparable to other presented works in Table 3. Therefore, the $\mathrm{Zn}_{2}(\mathrm{BDC})_{2}(\mathrm{DABCO}) \mathrm{MOF}$ with favorite properties can be used for extraction of nickel in water samples in optimized conditions.

Table 3. Comparing of USA-D- $\mu$-SPE procedure with other published method for nickel extraction in different matrixes

\begin{tabular}{lccccccc}
\hline Methods & Instrument & Metal & Matrix & LOD $\left(\boldsymbol{\mu g} \mathbf{L}^{-1}\right)$ & EF/PF & \%RSD & Ref \\
\hline SPE & F-AAS & $\mathrm{Ni} / \mathrm{Cu}$ & $\begin{array}{c}\text { Water and biological } \\
\text { samples }\end{array}$ & 0.6 & 200 & 3.1 & {$[31]$} \\
\hline IIPSPE & UV-VIS & $\mathrm{NI}$ & Water & 1.0 & 125 & 2.4 & {$[32]$} \\
\hline SPE & F-AAS & $\begin{array}{c}\mathrm{Ni}, \mathrm{Ca}, \\
\mathrm{Co}, \mathrm{Cu}\end{array}$ & Tea, Water & 1.0 & 10 & 2.0 & {$[33]$} \\
\hline ISSADSPE & F-AAS & $\mathrm{Ni}$ & Water & 0.7 & 50 & 2.5 & {$[34]$} \\
\hline NH-IS-SPE & HS-FAAS & $\mathrm{Ni}, \mathrm{Cr}, \mathrm{Co}$ & Water and Food & 2.74 & 205 & 3.5 & {$[35]$} \\
\hline SPE & ICP-OES & $\mathrm{Ni}$ & Water & 0.025 & 80 & 2.6 & {$[36]$} \\
\hline PPT-SPE & F-AAS & $\mathrm{Ni}$ & Water & 2.7 & 120 & 4.4 & {$[37]$} \\
\hline USA-D- $\mu$-SPE & ET-AAS & $\mathrm{Ni}$ & Water & 0.03 & 48.7 & 1.26 & This week \\
\hline
\end{tabular}

SPE: solid phase extraction

IIPSPE: Ion imprinted polymer- solid phase extraction

ISSADSPE: In-syringe solvent-assisted dispersive solid phase extraction

NH-IS-SPE: Needle hub in-syringe solid phase extraction

$\mu S-F A A S$ : micro-sampling flame atomic absorption spectrometry

PPT-SPE: Pipette tip Solid phase extraction 


\section{Conclusions}

In this study, the $\mathrm{Zn}_{2}(\mathrm{BDC})_{2}(\mathrm{DABCO}) \mathrm{MOF}$ adsorbent was synthesized by solvothermal method at $90{ }^{\circ} \mathrm{C}$ via the self-assembly metal centers and linkers using DMF solvent. Based on the results, the MOF was propped as a good candidate for nickel adsorption/extraction from water samples by USA-D- $\mu$-SPE procedure at $\mathrm{pH}=8$. The syringe cellulose acetate filters (SCAF, $0.2 \mu \mathrm{m}$ ) was used for separation of $\mathrm{Zn}_{2}(\mathrm{BDC})_{2}(\mathrm{DABCO}) \mathrm{MOF}$ from liquid phase and back-extraction of $\mathrm{Ni}$ ions from adsorbent before determined by ET-AAS. The $\mathrm{Zn}_{2}(\mathrm{BDC})_{2}(\mathrm{DABCO}) \mathrm{MOF}$ had the high recovery between 94.6-104.1 for Ni extraction from water samples. The proposed USA-D- $\mu$-SPE method had low LOD and RSD\% with good reusability about 21 times for water samples. Therefore, the $\mathrm{Zn}_{2}(\mathrm{BDC})_{2}(\mathrm{DABCO}) \mathrm{MOF}$ caused to create the efficient extraction of $\mathrm{Ni}$ ions in water samples based on chemical adsorption. The nickel concentration in remain solution has simply determined by ETAAS after back-extraction and dilution with DW.

\section{Acknowledgement}

The authors wish to thank from Department of Medical Nanotechnology, Tehran Medical Sciences, Islamic Azad University (IAUMS), Iranian Research Institute of Petroleum Industry (RIPI) and Iranian Petroleum Industry Health Research Institute (IPIHRI) for supporting this work.

\section{References}

[1] M.R. Mehmandoust, N. Motakef-Kazemi, F. Ashouri, Nitrate adsorption from aqueous solution by metal-organic framework MOF5, Iran. J. Sci. Technol. Trans. A-Sci., 43 (2019) 443-449.

[2] N. Kazemi, M. Yaqoubi, Synthesis of bismuth oxide: removal of benzene from waters by bismuth oxide nanostructures, Anal. methods Environ. Chem. J., 2 (2019) 5-14.

[3] M. Odar, N. Kazemi, Nanohydroxyapatite and its polycaprolactone nanocomposite for lead sorbent from aqueous solution,
Nanomed. Res. J., 5 (2020) 143-151.

[4] N. Motakef-Kazemi, A novel sorbent based on metal-organic framework for mercury separation from human serum samples by ultrasound assisted-ionic liquid-solid phase microextraction. Anal. methods Environ. Chem. J., 2 (2019) 67-78.

[5] E. Mosafayian Jahromy, N. Kazemi, Speciation of selenium (IV, VI) in urine and serum of thyroid patients by ultrasound-assisted dispersive liquid-liquid microextraction, Anal. methods Environ. Chem. J., 3 (2020) 5-17.

[6] P.B. Tchounwou, C.G. Yedjou, A.K. Patlolla, D.J. Sutton, Heavy metal toxicity and the environment, Mol. Clin. Environ. Toxicol., 101 (2012) 133-164.

[7] S.K. Seilkop, A.R. Oller, Respiratory cancer risks associated with low-level nickel exposure: An integrated assessment based on animal, epidemiological, and mechanistic data, Regul. Toxicol. Pharm., 37 (2003) 173190.

[8] Agency for Toxic Substances and Disease Registry (ATSDR), Toxicological profile for Nickel. Atlanta, GA: U.S. Department of Health and Human Services, Public Health Service, 2005.

[9] A.A. Satti, D.I. Temuge, S. Bektas, A.C. Sahin, An application of coacervate-based extraction for the separation and preconcentration of cadmium, lead, and nickel ions prior to their determination by flame atomic absorption spectrometry in various water samples, Turk. J. Chem., 40 (2016) 979-987.

[10] E.M. Sedykh, L.N. Bannykh, G.S. Korobeinik, N.P. Starshinova, Determination of nickel and vanadium in crude oils by electrothermal atomic absorption spectrometry and inductively coupled plasma atomic emission spectroscopy after mineralization in an 
autoclave, Inorg. Mater., 47 (2011) 1539 1543.

[11] Q. Zhang, J. Gao, Y.R. Qiu, Removal of Ni (II) and Cr (III) by complexationultrafiltration using rotating disk membrane and the selective separation by shear induced dissociation, Chem. Eng. Process., 135 (2019) 236-244.

[12] A. Dabrowski, Z. Hubicki, P. Podkościelny, E. Robens, Selective removal of the heavy metal ions from waters and industrial wastewaters by ion-exchange method, Chemosphere, 56 (2004) 91-106.

[13] M.M Matlock, B.S Howerton, D.A Atwood, Chemical precipitation of heavy metals from acid mine drainage, Water Res., 36 (2002) 4757-4764.

[14] T. Mohammadi, A. Moheb, M. Sadrzadeh, A. Razmi, Modelling of metal ion removal from wastewater by electrodialysis, Sep. Purif. Technol., 41 (2005) 73-82.

[15] V. Srivastava, C.H. Weng, V.K. Singh, Y.C. Sharma, Adsorption of nickel ions from aqueous solutions by nano alumina: kinetic, mass transfer, and equilibrium studies, J. Chem. Eng. Data, 56 (2011) 4.

[16] R. Acharya, S. Kolay, A.V.R. Reddy, Determination of nickel in finished product alloys by instrumental neutron activation analysis and spectrophotometry, J. Radioanal. Nucl. Chem., 294 (2012) 309-313.

[17] D.P.C. De Quadros, D.L.G. Borges, Direct analysis of alcoholic beverages for the determination of cobalt, nickel and tellurium by inductively coupled plasma mass spectrometry following photochemical vapor generation, Microchem. J., 116 (2014) 244248.

[18] S.Z. Mohammadi, H. Hamidian, L. Karimzadeh, Z. Moeinadini, Simultaneous extraction of trace amounts of cobalt, nickel and copper ions using magnetic iron oxide nanoparticles without chelating agent, J. Anal. Chem., 68 (2013) 953-958.

[19] M. Nassiri, R. Gharanjik, H. Hashemi, Spectrophotometric determination of copper and nickel in marine brown Algae after preconcentration with surfactant assisted dispersive liquid-liquid microextraction, Iran. J. Chem. Chem. Eng., 39 (2020) 117126.

[20] M. Behbahani, V. Zarezade, A. Veisi, F. Omidi, S. Bagheri, Modification of magnetized MCM-41 by pyridine groups for ultrasonic-assisted dispersive microsolid-phase extraction of nickel ions, Int. J. Environ. Sci. Technol., 16 (2019) 6431-6440.

[21] M. Rajabi, M. Abolhosseini, Magnetic dispersive micro-solid phase extraction merged with micro-sampling flame atomic absorption spectrometry using (Zn-Al $\mathrm{LDH})-(\mathrm{PTh} / \mathrm{DBSNa})-\mathrm{Fe}_{3} \mathrm{O}_{4}$ nanosorbent for effective trace determination of nickel(II) and cadmium(II) in food samples, Microchem. J., 159 (2020) 105450.

[22] S. Hajiashrafi, N. M. Kazemi, Green synthesis of zinc oxide nanoparticles using parsley extract, Nanomed. Res. J., 3 (2018) 44-50.

[23] N. M. Kazemi, A.A. Salimi, Chitosan nanoparticle for loading and release of nitrogen, potassium, and phosphorus nutrients, Iran. J. Sci. Technol. Trans A-Sci., 43 (2019) 2781-2786.

[24] N. Motakef-Kazemi, M. Sandalnia, In situ production and deposition of bismuth oxide nanoparticles on cotton fabric, Iran. J. Sci. Technol. Trans. A-Sci., 44 (2020) 1217-1223.

[25] S. Hajiashrafi, Preparation and evaluation of $\mathrm{ZnO}$ nanoparticles by thermal decomposition of MOF-5, Heliyon, 5 (2019) e02152. 
[26] B. Miri, S.A. Shojaosadati, A. Morsali, Application of a nanoporous metal organic framework based on iron carboxylate as drug delivery system, Iran. J. Pharm. Res., 17 (2018) 1164-1171.

[27] N. Motakef-Kazemi, S.A. Shojaosadati, A. Morsali, Evaluation of the effect of nanoporous nanorods $\mathrm{Zn}_{2}(\mathrm{bdc})_{2}$ (dabco) dimension on ibuprofen loading and release, J. Iran. Chem. Soc., 13 (2016) 1205-1212.

[28] F. Ataei, D. Dorranian, N. Motakef-Kazemi, Bismuth-based metal-organic framework prepared by pulsed laser ablation method in liquid, J. Theor. Appl. Phys., (2020). http:// doi: 10.1007/s40094-020-00397-y.

[29] N. Motakef-Kazemi, S.A. Shojaosadati, A. Morsali, In situ synthesis of a drug-loaded MOF at room temperature, Micropor. Mesopor. Mat., 186 (2014) 73-79.

[30] H. Shirkhanloo, Z. Karamzadeh, J. Rakhtshah, N. Motakef-Kazemi, A novel biostructure sorbent based on CysSB/MetSB@MWCNTs for separation of nickel and cobalt in biological samples by ultrasound assisteddispersive ionic liquid-suspension solid phase micro extraction, J. Pharm. Biomed. Anal., 172 (2019) 285-294.

[31] M. Karimi, Sh. Dadfarnia, A.M. Haji Shabani, Application of deep eutectic solvent modified cotton as a sorbent for online solidphase extraction and determination of trace amounts of copper and nickel in water and biological samples, Biol. Trace Elem. Res., 176 (2017) 207-215.

[32] H.R. Rajabi, S. Razmpour, Synthesis, characterization and application of ion imprinted polymeric nanobeads for highly selective preconcentration and spectrophotometric determination of $\mathrm{Ni} 2+$ ion in water samples, Spectrochim. Acta A, 153 (2016) 45-52.
[33] S.Z. Mohammadi, H. Hamidian, Tween 80 coated alumina: an alternative support for solid phase extraction of copper, nickel, cobalt and cadmium prior to flame atomic absorption spectrometric determination, A. J. Chem., 9 (2016) S1290-S1296.

[34] Jamshid Mofid Nakhaeia, Mohammad Reza Jamali, In-syringe solvent-assisted dispersive solid phase extraction followed by flame atomic absorption spectrometry for determination of nickel in water and food samples, Microchem. J., 144 (2019) 88-92.

[35] M. Shirania, F. Salaria, Needle hub insyringe solid phase extraction based a novel functionalized biopolyamide for simultaneous green separation/preconcentration and determination of cobalt, nickel, and chromium (III) in food and environmental samples with micro sampling flame atomic absorption spectrometry, Microchem. J. 152 (2020) 104340.

[36] M.S. Yalcin, S. Ozdemir, E. Kilınc, Preconcentrations of $\mathrm{Ni}(\mathrm{II})$ and $\mathrm{Co}(\mathrm{II})$ by using immobilized thermophilic geobacillus stearothermophilus SO-20 before ICP-OES determinations, Food Chem., 266 (2018) 126-132.

[37] M.A. Habila, Z.A. Alothman, E. Yilmaz, M. Soylak, Activated carbon cloth filled pipette tip for solid phase extraction of nickel(II), lead(II), cadmium(II), copper(II) and cobalt(II) as 1,3,4-thiadiazole-2,5-dithiol chelates for ultra-trace detection by FAAS, Int. J. Environ. Anal. Chem., 98 (2018) 171-181. 